\title{
Second trimester termination of pregnancy with misoprostol alone and misoprostol with isosorbide mononitrate: a comparative study
}

\author{
Pinkee Saxena $^{1 *}$, Neha Jaiswal ${ }^{1}$, Shashi Lata Kabra ${ }^{1}$, Vijay K. Kadam ${ }^{1}$, Vidushi Saxena ${ }^{2}$
}

${ }^{1}$ Departement of Obstetrics and Gynaecology, Deen Dayal Upadhyay Hospital, New Delhi, India
${ }^{2}$ Hamdard Institute of Medical Sciences and Research, New Delhi, India

Received: 11 December 2020

Accepted: 13 January 2021

*Correspondence:

Dr. Pinkee Saxena,

E-mail: drpinkee@hotmail.com

Copyright: () the author(s), publisher and licensee Medip Academy. This is an open-access article distributed under the terms of the Creative Commons Attribution Non-Commercial License, which permits unrestricted non-commercial use, distribution, and reproduction in any medium, provided the original work is properly cited.

\begin{abstract}
Background: Aim of the study was to compare the efficacy of misoprostol alone and misoprostol with isosorbide mononitrate in reducing the induction abortion time interval in second trimester termination of pregnancy.

Methods: A randomized control prospective study was conducted. Patients seeking second trimester abortions were randomized in to two groups. Group A received $400 \mathrm{ugm}$ of misoprostol per vaginum every 4 hours up to maximum of 5 doses. Group B patients received $400 \mathrm{ugm}$ of misoprostol and 40mg of isosorbide nitrate intravaginally. Repeat dose of $400 \mathrm{ugm}$ misoprostol and $20 \mathrm{mg}$ of isosorbide mononitrate was given every 4 hours up to a maximum of 5 doses. The induction to abortion interval and side effects of the drugs used were noted.

Results: A total 71 women seeking second trimester termination between 12 to 20 weeks gestation were recruited for the study. In group A, there were 36 patients and in group B there were 35 patients. In group A the mean induction abortion interval was $14.8 \pm 4.16$ hours while in group B the mean induction-abortion interval was $12.45 \pm 3.9$ hours. Patients treated with isosorbide mononitrate and misoprostol combination had statistically significantly lower induction abortion time interval when compared with misoprostol alone (p value 0.018).

Conclusions: The study demonstrates that the combination of isosorbide mononitrate and misoprostol is more effective for termination of second trimester pregnancy than misoprostol alone.
\end{abstract}

Keyword: Isosorbide mononitrate, Misoprostol, Second trimester, Abortion

\section{INTRODUCTION}

Second trimester abortion accounts for 10 to $15 \%$ of all induced abortions and is responsible for two thirds of all abortion related complications. ${ }^{1}$ In past, surgical methods were commonly practiced for termination of pregnancy. Nowadays with the availability of effective uterotonic drugs like prostaglandins and its analogue, medical termination of pregnancy is preferred. Misoprostol is commonly used for termination of pregnancy in second trimester. ${ }^{2}$ Drugs like mifepristone ${ }^{1}$ have been combined with it to reduce the induction abortion interval and improve outcome. ${ }^{3}$ Mifepristone has shown to be effective but it is expensive and may not be available at times.
Cervical ripening is an important prerequisite for the successful termination of a pregnancy. Nitric oxide donors like isosorbide mononitrate have been used as cervical ripening agents in first trimester and for induction of labour at term in the past. ${ }^{4-6}$

Nitric oxide donors induce production of matrix metalloproteinases namely MMP-1 and MMP-9, which are essential for collagen degradation. ${ }^{7}$ It also increases proinflammatory cytokines and prostaglandins. The use of these agents for second trimester termination of pregnancies can shortens the induction abortion delivery time. This study aims to evaluate the efficacy of isosorbide mononitrate in combination with misoprostol 
in shortening the induction to abortion interval in termination of pregnancy in second trimester.

\section{METHODS}

A prospective, randomized, comparative study was conducted in the department of obstetrics and gynaecology at Deen Dayal Upadhyay hospital, New Delhi. Patients requiring second trimester termination of pregnancy were recruited for the study. Inclusion criteria were singleton pregnancy between 12 to 20 weeks and requiring termination of pregnancy. Exclusion criteria were multiple gestations, previous uterine incision (caesarean section, myomectomy), patients in the process of abortion, genital infections and any underlying medical conditions like cardiac disease, diabetes mellitus or any known maternal allergy to prostaglandins or nitrates. The pregnant women who fulfilled the required criteria and were willing to participate in the study were recruited for the study. Ethical committee clearance was taken for the study. After counselling, a written informed consent was taken from all the patients. A detailed history was taken and a complete clinical examination was done for all patients. Routine investigations like haemoglobin, blood grouping and ultrasound to note the gestational age were done. The patients were randomized into two groups, group A and group B by closed envelope method. Patients in group A received 400 ugm of misoprostol per vaginum every 4 hours up to maximum of 5 doses. Group B patients received $400 \mathrm{ugm}$ of misoprostol and $40 \mathrm{mg}$ of isosorbide nitrate intravaginally. Repeat dose of $400 \mathrm{ugm}$ misoprostol and $20 \mathrm{mg}$ of isosorbide mononitrate was given every 4 hours up to a maximum of 5 doses. The induction to abortion time interval, the dose of drug required for complete abortion, the need for additional procedures for incomplete /failure of abortion and the side effects of the drugs used were noted.

Our estimated sample size was based on induction to abortion interval. In a previous study using a similar protocol the abortion interval was $20.4 \mathrm{hrs}$ in group 1 and $12.4 \mathrm{hrs}$ in group $2 .{ }^{8}$ Thus a sample size of 33 patients per group with an effect size of 0.8 and $90 \%$ power for detecting a mean difference of $8 \mathrm{hrs}$ in induction to abortion interval between any two groups at an alpha level of 0.05 . In this study total of 71 patients were taken. Statistical testing was conducted with the statistical package for the social science system version SPSS 17.0. Continuous variables were presented as mean SD or median (IQR) for non-normally distributed data. Categorical variables were expressed as frequencies and percentages. The comparison of normally distributed continuous variables between the groups was performed using ANOVA with appropriate post hoc test for paired comparisons of groups. Nominal categorical data between the groups was compared using Chi-squared test or Fisher's exact test as appropriate. For all statistical tests, a $\mathrm{p}$ value less than 0.05 was taken to indicate a significant difference.

\section{RESULTS}

A total 71 women seeking mid trimester termination between 12 to 20 weeks gestation were recruited for the study. In group A, there were 36 patients and in group B there were 35 patients. Clinical characteristic of the two groups is given in Table 1. Both the groups were found to be similar in their clinical characteristics. The indications for termination of pregnancy are summarized in Table 2. The most common indication for termination of pregnancy was missed abortion, $50 \%$ in group $\mathrm{A}$ and $51.4 \%$ in group B respectively.

Table 1: Clinical characteristics of the two study groups.

\begin{tabular}{|llll|}
\hline Variables & Group A & Group B & P \\
\hline Age (years) & $27 \pm 5.66$ & $26.37 \pm 5.63$ & 0.64 \\
\hline Nullipara & 14 & 15 & 0.81 \\
\hline Multipara & 22 & 20 & 0.81 \\
\hline $\begin{array}{l}\text { Gestational } \\
\text { age (weeks) }\end{array}$ & $15.91 \pm 2.27$ & $16.68 \pm 2.33$ & 0.16 \\
\hline
\end{tabular}

Table 2: Indications for second trimester termination of pregnancy.

\begin{tabular}{|llll|}
\hline Indications & Group (\%) & Total \\
\hline Anomalous baby & $3(8.3)$ & $3(8.5)$ & 65 \\
\hline Missed abortion & $18(50)$ & $18(51.4)$ & 36 \\
\hline PPROM & $1(2.7)$ & $2(5.7)$ & 3 \\
\hline Anhydramnios & $2(5.5)$ & $4(11.4)$ & 6 \\
\hline $\begin{array}{l}\text { Contraceptive } \\
\text { failure }\end{array}$ & $10(27.7)$ & $7(20)$ & 17 \\
\hline Social cause & $2(5.5)$ & $1(2.8)$ & 3 \\
\hline Total & 36 & 35 & 71 \\
\hline
\end{tabular}

In group $\mathrm{A}$ the mean induction abortion interval was 14.8 \pm 4.16 hours while in group B the mean induction abortion interval was $12.45 \pm 3.9$ hours. Patients treated with isosorbide mononitrate and misoprostol combination had statistically significantly lower induction abortion time interval when compared with misoprostol alone ( $p$ value-0.018). On comparing the mean induction abortion time interval in nullipara and multipara within each group it was observed that time taken for complete abortion was statistically insignificant. In group A the mean induction abortion interval was $15.08 \pm 4.76$ hours in nullipara and $14.20 \pm 3.75$ hours in multipara, $p$ value-0.27. In group $B$ the mean induction abortion interval was 13.26 \pm 4.04 hours in nullipara and $11.85 \pm 3.83$ hours in multipara, $\mathrm{p}$ value- 0.29 .

In the study the total dose of misoprostol administered to patients in group A was 1488.88 \pm 377.79 ugm and group B was $1268.27 \pm 381.76$ ugm. Combined group required lower dose of misoprostol which was statistically significant ( $\mathrm{p}$ value 0.017). 97.1\% patients in group A and $100 \%$ patients in group B aborted completely after 
induction with drugs. In group A one patient (2.85\%) failed to abort completely after receiving five doses of the drug.

Difference in hemoglobin levels post abortion was $1.3 \pm 1.57 \mathrm{mg} / \mathrm{ml}$ in group $\mathrm{A}$ and $1.39 \pm 0.39 \mathrm{mg} / \mathrm{ml}$ in group B which was statistically insignificant ( $\mathrm{p}$ value$0.79)$.

Pain was the most common side effect noted in both the groups as seen in the Table 3. Other side effects noted were fever and diarrhea. None of the side effects specific to nitrates was observed in our patients.

Table 3: Side effects.

\begin{tabular}{|llll|}
\hline Side effects & Group & & Total \\
\hline Pain & A (36) & B (35) & \\
\hline Diarrhoea & 28 & 20 & 48 \\
\hline Fever & 1 & 0 & 1 \\
\hline Headache & 2 & 1 & 3 \\
\hline Palpitation & 0 & 0 & 0 \\
\hline
\end{tabular}

\section{DISCUSSION}

Second trimester abortions are painful and stressful procedures. Misoprostol is currently used for termination of pregnancy in second trimester alone or with mifepristone. Combining misoprostol with other drugs helps to reduce the abortion induction time interval.

Nitric oxide donors like isosorbide mononitrate aids in the cervical ripening. ${ }^{6}$ Nitric oxide acts on the collagen tissue and induces production of prostaglandins and other mediators of inflammation. This leads to softening of the cervical tissue locally and can aid in decreasing the induction abortion interval in patients seeking second trimester abortions.

We studied the effect of combination of misoprostol and isosorbide mononitrate on second trimester abortion. The mean duration between induction to abortion was $14.8 \pm 4.16$ hours in group A and 12.45 \pm 3.9 hours in group $B$ respectively ( $p$ value- 0.018 ). This reduced induction abortion time interval in group B was due to the added effect of isosorbide mononitrate on cervical ripening.

Similarly, in a study conducted by Mousiolis et al the mean duration for complete abortion was 20.4 hours (95\%CI $=16.63-24.17)$ for women in misoprostol group compared with 12.4 hours $(95 \% \mathrm{CI}=10.33-14.47)$ in women receiving misoprostol plus isosorbide mononitrate. ${ }^{8}$ The $\mathrm{p}$ value $(\mathrm{p} \leq 0.05)$ was statistically significant. Shanthi Sivakumar et al in their study reported that the mean time taken for complete abortion in misoprostol group was 9 hours 55 minutes $( \pm 4$ hours 42 minutes) whereas it was 7 hours 36 minutes ( \pm 3 hours 11 minutes) in misoprostol plus isosorbide mononitrate group. ${ }^{9}$ This difference was statistically significant. They had given mifepristone to all their patients. This may be the reason for reduced induction abortion interval seen in their study compared to ours. Eppel et al in their study found that gemeprost when combined with $40 \mathrm{mg}$ isosorbide mononitrate resulted in higher abortion rate than gemeprost alone. ${ }^{8}$ Combination group had success rate of $68 \%$ where as gemeprost only group had a success rate of $38 \%$.

In the study conducted by Mousiolis et al the mean induction abortion interval in nulliparous was 22.3 hours in misoprostol group in contrast to 15 hours in misoprostol plus isosorbide mononitrate group ( $\mathrm{p}$ value $0.005){ }^{8}$ The mean time elapsed for multiparous in misoprostol group was 18.3 hours in contrast to 9.8 hours in misoprostol plus isosorbide mononitrate group. This difference was also statistically significant. This may be due to alterations in cervical compliance that is observed between primigravida and multigravida women. ${ }^{10}$ In our study the mean abortion time observed in nullipara was more than multipara within each group, but it was statistically insignificant.

Headache and palpitations have been reported with isosorbide mononitrate. ${ }^{11,12}$ Our patients did not complain of headache or palpitations. This may be due to first pass effect of vaginally administered isosorbide mononitrate. Similarly, Mousiolis ${ }^{8}$ et al also did not report any side effect attributed specifically to nitrates.

\section{CONCLUSION}

Our study concludes that misoprostol plus isosorbide mononitrate is more effective in reducing the induction abortion time interval than misoprostol alone. This combination is a safe, effective and relatively inexpensive means of performing mid trimester termination of pregnancy.

\section{Funding: No funding sources}

Conflict of interest: None declared

Ethical approval: The study was approved by the Institutional Ethics Committee

\section{REFERENCES}

1. Medical management of abortion. Geneva: World Health Organization; 2018. Licence: CC BY-NC-SA 3.0 IGO.

2. Wildschut H, Both MI, Medema S, Thomee E, Wildhagen MF, Kapp N. Medical methods for midtrimester termination of pregnancy. Cochrane Library. 2011;(1):CD005216

3. Vargas J, Diedrich J. Second-trimester induction of labor. Clin obstetr gynecol. 2009;52(2):188-97.

4. Promsonthi P, Preechapornprasert D, Chanrachakul B. Nitric oxide donors for cervical ripening in firsttrimester surgical abortion. Cochrane Database Syst Rev. 2009;1:4. 
5. Abdellah MS, Hussien M, AboAlhassan A. Intravaginal administration of isosorbide mononitrate and misoprostol for cervical ripening and induction of labour: a randomized controlled trial. Arch gynecol obstetr. 2011;284(1):25-30.

6. Collingham JP, Fuh KC, Caughey AB, Pullen KM, Lyell DJ, El-Sayed YY. Oral misoprostol and vaginal isosorbide mononitrate for labor induction: a randomized controlled trial. Obstetr Gynecol. 2010;116(1):121-6.

7. Radulovic NV, Ekerhovd E, Abrahamsson G, Norström A. Cervical priming in the first trimester: morphological and biochemical effects of misoprostol and isosorbide mononitrate. Acta obstetricia et gynecologica Scandinavica. 2009;88(1):43-51.

8. Mousiolis A, Sindos M, Papantoniou N, Antsaklis A. Can isosorbidemononitrate be useful in second trimester termination of pregnancies? Contraception. 2013;88(1):41-4.

9. Sivakumar S, Fathima R, Radha R. Comparison of misoprostol and misoprostol with isosorbide mononitrate in second trimester termination of pregnancy. J Evidence Based Med Healthcare. 2016;3(63):3424-9.

10. Dickinson JE, Brownell P, McGinnis K, Nathan EA. Mifepristone and second trimester pregnancy termination for fetal abnormality in Western Australia: worth the effort. Aus N Z J Obstetr Gynaecol. 2010;50(1):60-4.

11. Duhan N, Gupta S, Dahiya K, Sirohiwal D, Rohilla S. Comparison of isosorbide mononitrate and misoprostol for cervical ripening in termination of pregnancy between 8 and 12 weeks: a randomized controlled trial. Arch gynecol obstetr. 2011;283(6):1245-8.

12. Agarwal K, Batra A, Batra A, Dabral A, Aggarwal A. Evaluation of isosorbide mononitrate for cervical ripening prior to induction of labor for postdated pregnancy in an outpatient setting. Int $\mathbf{J}$ Gynaecol Obstet. 2012;118(3):205-9.

Cite this article as: Saxena P, Jaiswal N, Kabra SL Kadam VK, Saxena V. Second trimester termination of pregnancy with misoprostol alone and misoprostol with isosorbide mononitrate: a comparative study. Int J Reprod Contracept Obstet Gynecol 2021;10:971-4. 